J. MED. MICROBIOL.-VOL. 18 (1984) 17-25

(C) 1984 The Pathological Society of Great Britain and Ireland

\title{
CHARACTERISATION OF TARGET ANTIGEN OF CELL-MEDIATED IMMUNITY IN MYCOBACTERIUM TUBERCULOSIS H37RV
}

\author{
Sandhya Hattikudur and R. S. Kamat \\ Department of Immunology, Haffkine Institute, Parel, Bombay 400 012, India
}

\begin{abstract}
SUmmaRY. Antigen participating in cell-mediated immunity was isolated from a sonic extract of Mycobacterium tuberculosis H37Rv. The purified antigen had a mol. wt 150000-200 000, based upon its Rf in $7.5 \%$ polyacrylamide gel in the presence of sodium dodecyl sulphate. In simple agarose gel electrophoresis it had an $\mathrm{Rf}$ of 0.85 . The protein in its native state was identified in the sonic extract with an antiserum to the purified antigen; it too had an $\mathrm{Rf}$ of 0.85 in agarose gel electrophoresis. The purified antigen elicited a delayed hypersensitivity response and stimulated the generation of activated macrophages in mice immunised with $M$. tuberculosis H37Rv.
\end{abstract}

\section{INTRODUCTION}

Identification of antigens responsible for cell-mediated immunity to Mycobacterium tuberculosis would assist the study of problems such as cross-reactivity, immune suppression, deviation and immunity acquired as a result of infection with environmental mycobacteria. The alleged failure of BCG in certain regions emphasises the need to understand the antigenic relations of mycobacteria.

In a recent report (Deshpande, Sharma and Kamat, 1982) we described the partial characterisation of a lipoprotein antigen of $M$. tuberculosis H37Rv which was capable of eliciting a delayed hypersensitivity response. In this paper we present the physicochemical and immunological characteristics of this antigen.

\section{Materials AND MethodS}

Bacteria. M. tuberculosis H37Rv (NCTC7416) was obtained from the National Collection of Type Cultures, Colindale Avenue, London NW9 5HT. Salmonella enteritidis $(\mathrm{O} 1,9,12 ; \mathrm{H} \mathrm{g}$, $\mathrm{m}$ ) was isolated from naturally infected mice in the animal colony of the Haffkine Institute.

Antigenic extract of $M$. tuberculosis $\mathrm{H} 37 \mathrm{Rv}$ was prepared as described by Deshpande $e$ al . (1982) from bacteria grown for 6-8 weeks on the medium of Doub and Youmans (1950). The cells were killed by irradiation with 2.4 megarad gamma radiation from a ${ }^{60} \mathrm{Co}$ source. The killed bacterial cell mass was washed three times with phosphate buffered saline (PBS, $p \mathrm{H} \mathrm{7 \cdot 2)}$ and the cells disrupted by sonic disintegration (Sonifier B-30, Branson, USA). The sonicate was centrifuged at $50000 \mathrm{~g}$ for $1 \mathrm{~h}$ to remove the cell debris and the supernate concentrated by vacuum dialysis until the protein concentration reached $10 \mathrm{mg} / \mathrm{ml}$ as determined by the method of Lowry et al. (1951). It was then dialysed against tris-buffered saline (TBS- $0.01 \mathrm{M}$ tris- $\mathrm{HCl}$ in 
$0.15 \mathrm{M} \mathrm{NaCl}, p \mathrm{H} \mathrm{8.0)}$ for $48 \mathrm{~h}$ with repeated changes of the buffer. Papain (Sigma Chemical Co., USA) was added to the extract to give a final concentration of enzyme $1.0 \mathrm{mg} / 5.0 \mathrm{mg}$ of protein; $0.1 \mathrm{M} \mathrm{L}$-cysteine (Sigma) was added in the proportion of $0.2 \mathrm{ml}$ to $10 \mathrm{ml}$ of the antigenic extract. After $2 \mathrm{~h}$ at $37^{\circ} \mathrm{C}$ the digestion was terminated by the addition of $0.2 \mathrm{ml} \mathrm{of} 0.13 \mathrm{M}$ iodoacetamide to $10 \mathrm{ml}$ of the digestion mixture. The digest was chilled and centrifuged at $10000 \mathrm{~g}$ for $30 \mathrm{~min}$. The supernate was used for the preparation of the purified antigen as described below.

Gel filtration chromatography. The supernate obtained by centrifugation of the papaindigested extract was concentrated by vacuum dialysis to $3.0 \mathrm{ml}$ containing $70.0 \mathrm{mg}$ of protein, loaded on to a Sephadex G200 column $(80 \times 2.5 \mathrm{cms})$ and eluted with $0.01 \mathrm{M}$ TBS. The eluate was monitored for protein content by absorbance readings at $280 \mathrm{~nm}$. Four peaks were obtained and the fractions below each peak were pooled. These were tested for their capacity to evoke a delayed hypersensitivity response in patients with pulmonary tuberculosis.

Analytical isoelectric focusing (IEF). A modification of the method of Vesterberg (1980) was used. A $1 \% \mathrm{w} / \mathrm{v}$ agarose gel (IEF grade, Pharmacia, Sweden) was prepared in sucrose $12.5 \%$ $\mathrm{w} / \mathrm{v}$ containing ampholine $2 \% \mathrm{w} / \mathrm{v}(p \mathrm{H} 3 \cdot 5-5 \cdot 0 ; \mathrm{LKB}$, Sweden $)$. Layers $1.5 \mathrm{~mm}$ thick were made on $2.5 \times 7.5-\mathrm{cm}$ slides. The anode compartment contained $0.05 \mathrm{M} \mathrm{H}_{2} \mathrm{SO}_{4}$ and the cathode compartment $1.0 \mathrm{M} \mathrm{NaOH}$. The slides were prefocused for $30 \mathrm{~min}$ at $2 \mathrm{~mA} / \mathrm{slide}$ and $0.04 \mathrm{ml}(15$ $\mu \mathrm{g}$ of protein) of a sample was applied $5 \mathrm{~mm}$ on the anodal side of the cathode. The current was kept constant at $2 \mathrm{~mA}$ /slide until completion of protein separation, as indicated by the current falling to zero which, on average, took $4-5 \mathrm{~h}$ at $4{ }^{\circ} \mathrm{C}$. The slides were washed in trichloracetic acid $10 \% \mathrm{w} / \mathrm{v}$ and stained for protein with Coomassie Brilliant Blue R250, for carbohydrate with periodic acid-Schiff (PAS) and for lipid with Sudan Black by the technique of Hughes, Lee and Balfour (1980).

Preparatory IEF. Layers of $1 \%$ agarose, $1.5 \mathrm{~mm}$ thick were made on $7.5 \times 7.5-\mathrm{cm}$ glass slides. They were prefocused at a constant current of $8 \mathrm{~mA}$ for $30 \mathrm{~min}$ and $0.4 \mathrm{ml}(150 \mu \mathrm{g}$ of protein) of sample then applied. Focusing was performed at $8 \mathrm{~mA}$ until the current fell to zero. Bands of precipitated protein were cut out, homogenised in $3 \mathrm{ml}$ of $0.15 \mathrm{M} \mathrm{NaCl}$ containing Tween $800.01 \%$, the suspension centrifuged at $30000 \mathrm{~g}$ for $30 \mathrm{~min}$ and the supernate dialysed against the eluant to remove ampholine.

Two-dimensional immunoelectrophoresis (IEP) (Laurell, 1965). Thin layers of agarose gel $1 \%$ in $0.02 \mathrm{~m}$ barbital buffer $(\mathrm{pH} \mathrm{8.0)}$ ) were made on $7.5 \times 7.5$-cm glass slides. Electrophoresis in the first dimension was performed without antibody in the gel at $8 \mathrm{~mA}$ for $40 \mathrm{~min}$ at $4^{\circ} \mathrm{C}$. This was followed by electrophoresis at right angles into gels containing antiserum $2.5 \%$, at $3 \mathrm{~mA}$ for $16 \mathrm{~h}$ at $4^{\circ} \mathrm{C}$. The slides were washed, dried and stained with Coomassie Brilliant Blue R 250 .

Rocket immunoelectrophoresis. The sample was electrophoresed into a $1 \%$ agarose gel containing antiserum $2.5 \%$ at $3 \mathrm{~mA}$ for $16 \mathrm{~h}$ at $4{ }^{\circ} \mathrm{C}$.

Agarose gel diffusion precipitation (Ouchterlony and Nilsson, 1978). An agarose gel $1 \%$ in $0.15 \mathrm{M} \mathrm{NaCl}$ was poured on to $7.5 \times 2.5-\mathrm{cm}$ glass slides to give a layer $2-3 \mathrm{~mm}$ thick. Wells, 5 $\mathrm{mm}$ in diameter, were punched in a three way system with a distance of $13 \mathrm{~mm}$ between any two wells. These were filled repeatedly with antiserum or the antigen under study and the slides stored at $4^{\circ} \mathrm{C}$ overnight. The slides were washed, dried and stained for immunoprecipitates as before.

Polyacrylamide gel 'disk' electrophoresis (PAGE) was done in $7.5 \%$ gels by the method of Maizel (1971). Antigen $(50 \mu \mathrm{g})$ was taken into $0 \cdot 1 \mathrm{ml}$ of $0.01 \mathrm{M}$ phosphate buffer containing $1 \%$ sodium dodecyl sulphate (SDS) $1 \%$ and boiled for $1 \mathrm{~min}$. The buffer used in the electrophoresis also contained SDS $1 \%$.

Delayed hypersensitivity tests were made in Swiss white mice weighing 18-20 g using the foot pad swelling technique of Gray and Jennings (1955). A 0.03-ml volume of bacterial sonicate containing protein $50 \mu \mathrm{g}$ was injected into a hind footpad and measurements of foot pad thickness were taken before injection and $24 \mathrm{~h}$ and $48 \mathrm{~h}$ after injection of the antigen. Tests were also made in patients with pulmonary tuberculosis whose sputa contained acid-fast bacilli. The test antigen, $0 \cdot 1 \mu \mathrm{g}$ of protein in $0 \cdot 1 \mathrm{ml}$ of normal saline, was injected intradermally into the left forearm and 5 TU of PPD-S (Serum Inst., Denmark) was injected intradermally as a positive control in the opposite arm. The reactions were examined 24 and $48 \mathrm{~h}$ later. Erythema and induration greater than $8.0 \mathrm{~mm}$ was taken as a positive reaction. Each antigenic fraction was tested in at least five patients who had given a positive reaction to PPD-S. 
Generation of activated macrophages by effector T cells (Nair and Kamat, 1982). Swiss white mice weighing $18-20 \mathrm{~g}$ were immunised with $0.2 \mathrm{mg}$ wet weight of live $M$. tuberculosis $\mathrm{H} 37 \mathrm{Rv}$. Twelve weeks later they were tested for delayed hypersensitivity with the purified antigen obtained by preparatory IEF.

Mice that gave positive reactions were given $50 \mu \mathrm{g}$ of the purified antigen by intraperitoneal injection and, as controls, animals that gave positive delayed hypersensitivity reactions received saline in place of the antigen and normal mice received the antigen; $36 \mathrm{~h}$ later, each mouse was given an intraperitoneal injection of $2 \times 10^{4}$ Salmonella enteritidis cells preopsonised with rabbit antibody to the homologous organism. The mice were killed $5 \mathrm{~min}$ later by cervical dislocation. Chilled Hanks balanced salt solution (HBSS) containing rabbit antibody against $S$. enteritidis $2 \% \mathrm{v} / \mathrm{v}$, newborn calf serum $10 \% \mathrm{v} / \mathrm{v}$ and heparin $20 \mathrm{IU}$ was immediately injected intraperitoneally, the abdomen massaged and the contents aspirated. The peritoneal exudate cells from several mice were pooled and washed. The numbers of unphagocytosed bacteria in the washings were estimated by dilution and plating and expressed as colony forming units (cfu).

The washed pellet of peritoneal exudate cells was suspended $\left(6 \times 10^{6} \mathrm{cells} / \mathrm{ml}\right)$ in warm HBSS containing newborn calf serum $12 \% \mathrm{v} / \mathrm{v} ; 1-\mathrm{ml}$ portions were incubated at $37^{\circ} \mathrm{C}$ for various periods and one portion was chilled immediately. After incubation, $0 \cdot 1 \mathrm{ml}$ of saponin was added to a final concentration of $2 \cdot 5 \% \mathrm{v} / \mathrm{v}$ to lyse the peritoneal exudate cells; lysates were kept on ice until dilution and plating for counting of viable bacteria. The percentage of organisms killed at each time was calculated with reference to the number of intracellular cfu at time 0.

Antisera. Antiserum $l$ was raised in rabbits by four immunisations with $1.0 \mathrm{ml}$ of the crude sonic extract of $M$. tuberculosis H37Rv containing protein $1.0 \mathrm{mg} / \mathrm{ml}$ in Freund's incomplete adjuvant on days $1,7,14$ and 28 . The rabbits were bled one week after the last injection and the antibody titre determined by gel diffusion precipitation. The antiserum employed in the study had a titre of 64 . The antiserum showed 27 distinct precipitin arcs in two-dimensional-IEP against crude sonic extract (Deshpande et al., 1982). Antiserum 2 was raised similarly, employing four immunisations with $1.0 \mathrm{ml}$ of purified delayed-hypersensitivity-eliciting antigen of $M$. tuberculosis H37Rv $100 \mu \mathrm{g} / \mathrm{ml}$ in Freund's incomplete adjuvant. The antiserum had a titre of 32 .

\section{RESULTS}

\section{Purification of the delayed-hypersensitivity-eliciting antigen}

Of the four peaks obtained by gel filtration of the papain-digested sonicate, one was composed of a protein of large mol. wt (150000-200000). This elicited a delayed hypersensitivity response when tested in patients with pulmonary tuberculosis. When subjected to isoelectric focusing in a $p \mathrm{H}$ gradient of $3 \cdot 5-5 \cdot 0$, six bands were formed (fig. 1). The protein in the broad band, no. 5, corresponding to a pI value of $4-4.5$ elicited a delayed hypersensitivity response in man; band no. 4 showed a weak reaction, while the

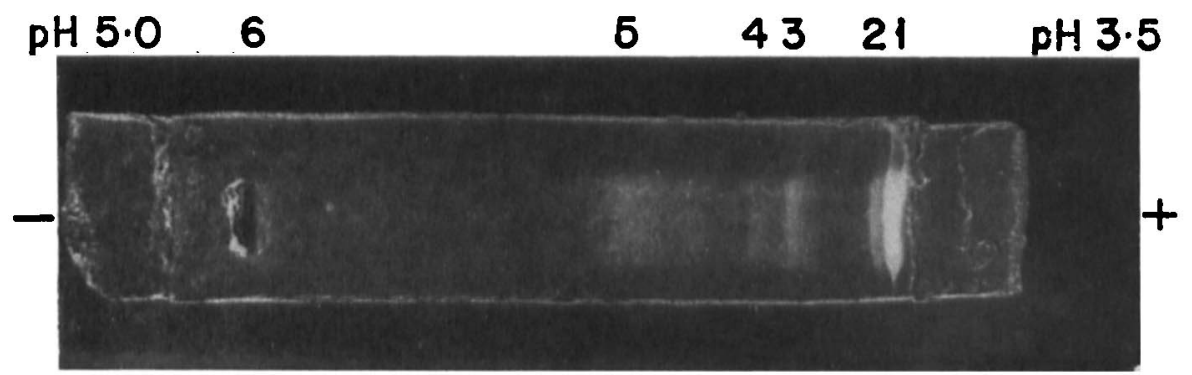

FIG. 1.-Analytical IEF of extract of $M$. tuberculosis $\mathrm{H} 37 \mathrm{Rv}$ on $2.5 \times 7.5-\mathrm{cm}$ agarose slide; protein bands are labelled $1-6$. 


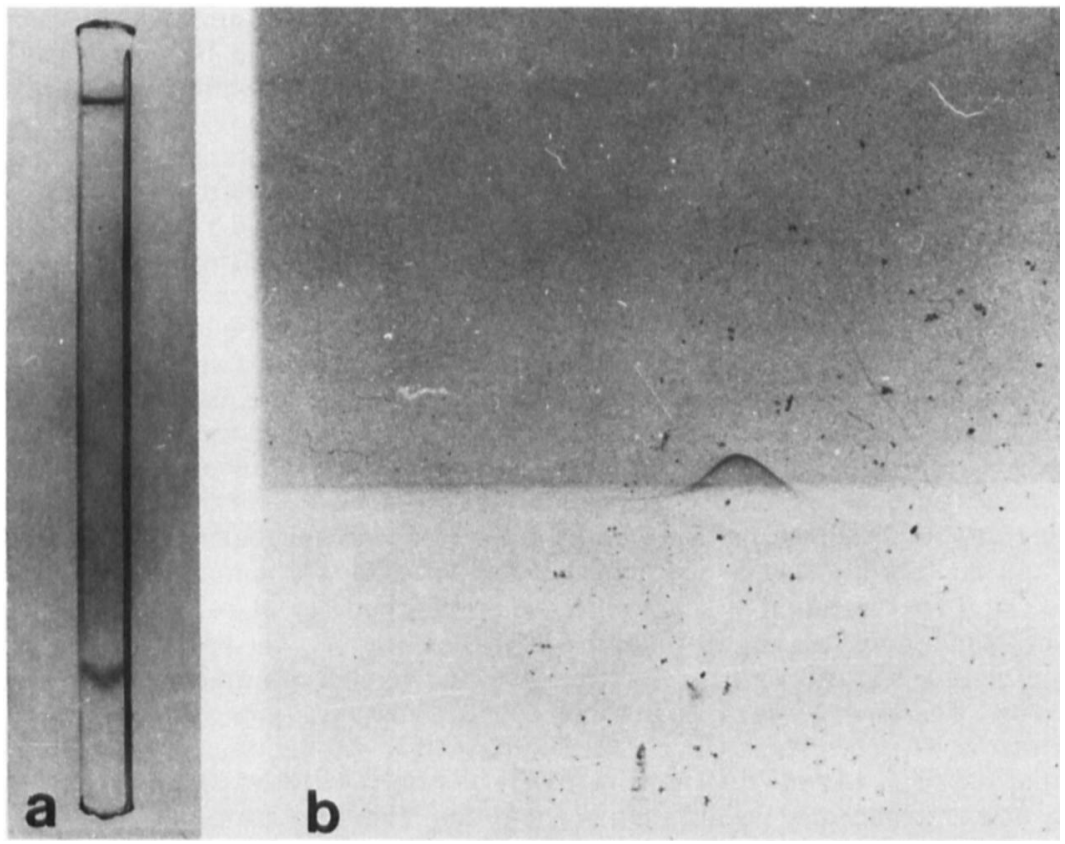

FIG. 2.-Electrophoretic profile of purified target antigen: (a) PAGE in $7.5 \%$ gel (lower line represents dye front); (b) two-dimensional IEP against antiserum 1 (see Methods).

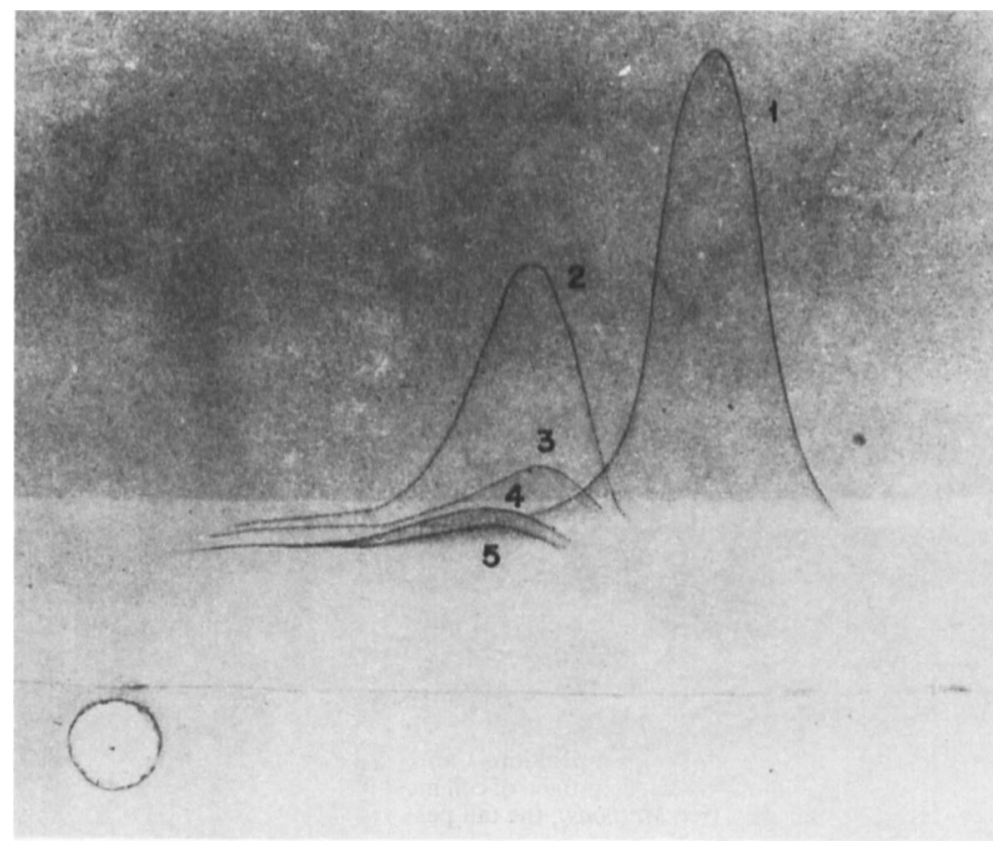

Frg. 3.-Two-dimensional IEP of crude sonic extract of $M$. tuberculosis H37Rv against antiserum 2; precipitation peaks are labelled $1-5$. 
other bands were un-reactive in tests for delayed hypersensitivity. All the bands were Sudan Black-negative, indicating that they were free of lipid; band no. 5, responsible for delayed hypersensitivity response, was also PAS negative.

\section{$R f$ values of the purified delayed-hypersensitivity-eliciting antigen}

The purified antigen obtained by preparatory IEF gave a single band with an $\mathrm{Rf}$ of $0 \cdot 1$ when subjected to electrophoresis in polyacrylamide gel. This indicated a mol. wt of c. 150000-200000 (fig. 2a).

In two-dimensional IEP against antiserum 1, a single precipitin peak could be seen, corresponding to an $\mathrm{Rf}$ value of 0.85 (fig. $2 \mathrm{~b}$ ). An identical result was obtained when antiserum 2 was used.

Characterisation of the native delayed-hypersensitivity-eliciting antigen in the crude sonicate

The crude sonicate of $M$. tuberculosis H37Rv gave five precipitin peaks when tested against antiserum 2 in two dimensional IEP (fig. 3). Precipitin peak 1 had an Rf of

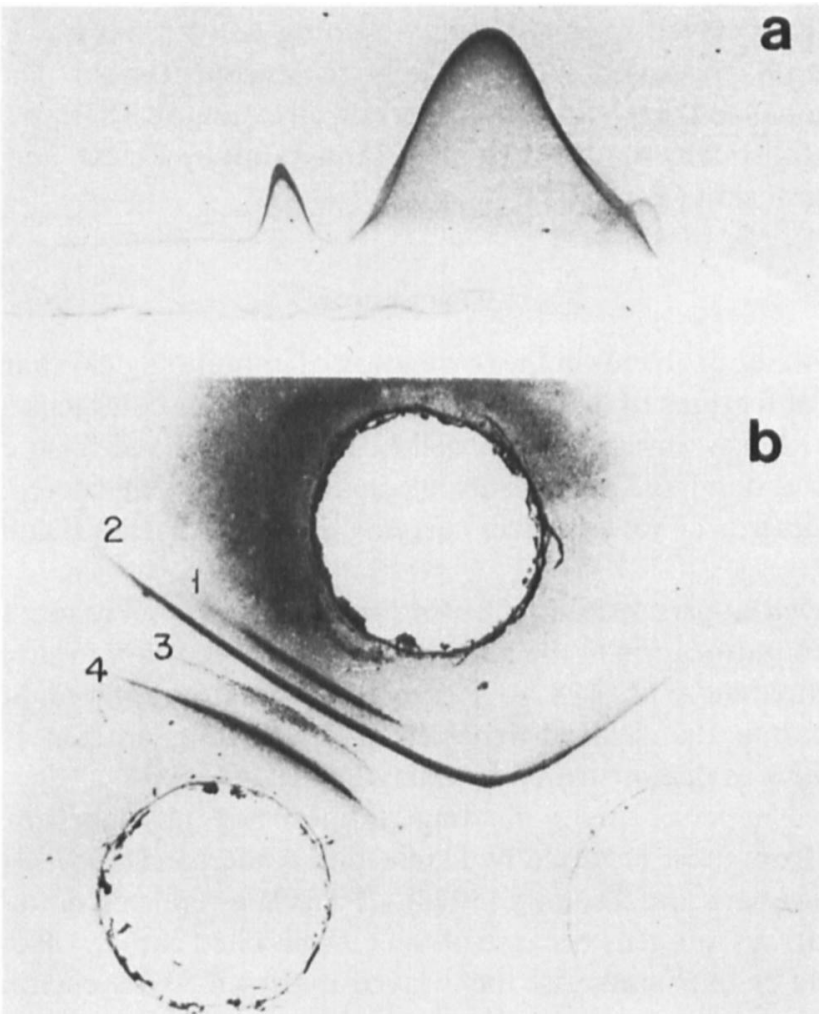

FIG. 4.-Proof of antigenic identity between peak no. 1 antigen (fig. 3) from the crude sonic extract of $M$. tuberculosis H37Rv and purified target antigen of cell mediated immunity. (a) Rocket immunoelectrophoresis against antiserum 2 (see Methods); the tall peak is the sonic extract. (b) Simple gel diffusion analysis; the top well contained antiserum 2, the left-hand well contained the crude sonic extract of $M$. tuberculosis $\mathrm{H} 37 \mathrm{Rv}$ and the right-hand well the purified delayed-hypersensitivity-eliciting antigen of $M$. tuberculosis H37Rv. 
0.85 , i.e., the same $\mathrm{Rf}$ as that of the purified antigen. When eluted from the gel, precipitin peak 1 elicited a delayed hypersensitivity response in patients with pulmonary tuberculosis.

Fig. 4a shows that peak 1 and purified antigen gave lines of identity when tested against antiserum 2 by rocket immunoelectrophoresis. Fig. $4 \mathrm{~b}$ shows that in a simple gel diffusion test the crude sonicate formed four precipitin lines with antiserum 2 and one of these was identical with the single precipitin line formed by the purified antigen.

\section{Generation of activated macrophages by purified delayed-hypersensitivity-eliciting antigen of $H 37 R v$.}

Peritoneal exudate cells from mice immunised 3 months earlier and showing a delayed hypersensitivity response to H37Rv antigen killed $13 \cdot 5,19 \cdot 7,32 \cdot 3,20 \cdot 8$ and $9 \cdot 1 \%$ of the phagocytosed salmonellae in $5,10,15,20$ and 30 min respectively (fig. 5). Cells from similarly immunised mice stimulated $36 \mathrm{~h}$ before the assay with $50 \mu \mathrm{g}$ of purified delayed-hypersensitivity-eliciting antigen intraperitoneally killed $30 \cdot 5,36 \cdot 4$, $52.2,56.8$ and $57.8 \%$ of the phagocytosed salmonellae in $5,10,15,20$ and $30 \mathrm{~min}$ respectively. Peritoneal exudate cells from non-immune normal mice stimulated with $50 \mu \mathrm{g}$ of purified delayed-hypersensitivity-eliciting antigen did not kill a significant number of the phagocytosed salmonellae at the various times. The counts of the surviving salmonellae at each time in the peritoneal exudate cells from the three groups of mice were statistically analysed by the Mann-Whitney $U$ test, and the differences were highly significant $(P<0 \cdot 01)$.

\section{DisCUSSION}

One of the major problems in the correlation of immunological characteristics with physicochemical features of mycobacterial macromolecular antigens is the molecular heterogeneity. Many antigens of the cell extracts are derived from cell walls where repeating units abound and, as a result, the individual antigenic determinants may be present on fragments of various sizes carrying different charges (Daniel and Janicki, 1978).

As the delayed-hypersensitivity-eliciting antigen was found to be a lipoprotein and not amenable to purification in the native state, it was necessary to subject it to papain digestion (Deshpande et al., 1982). Repeated chromatography on Sephadex G-200 could not separate the delayed-hypersensitivity-eliciting antigen from five other protein impurities as demonstrated by analytical IEF.

Our delayed-hypersensitivity-eliciting antigen has physicochemical properties quite different from those reported by Daniel and Anderson (1978), Gupta and Landi (1980) and Kuwabara and Tsumita (1974). From the reported data, it is difficult to compare the various antigens because of the reasons cited earlier. However, a logical approach would be to characterise the delayed-hypersensitivity-eliciting antigen in its native state in the crude sonic extract in terms of its reactivity with a marker antiserum. Employing this rationale, antiserum 2 was raised and the peak-1 antigen with an Rf value of 0.85 in immunoelectrophoresis was identified.

As expected, the purified delayed-hypersensitivity-eliciting antigen showed a single precipitin peak against antiserum 2 in two-dimensional IEP. However, the same 


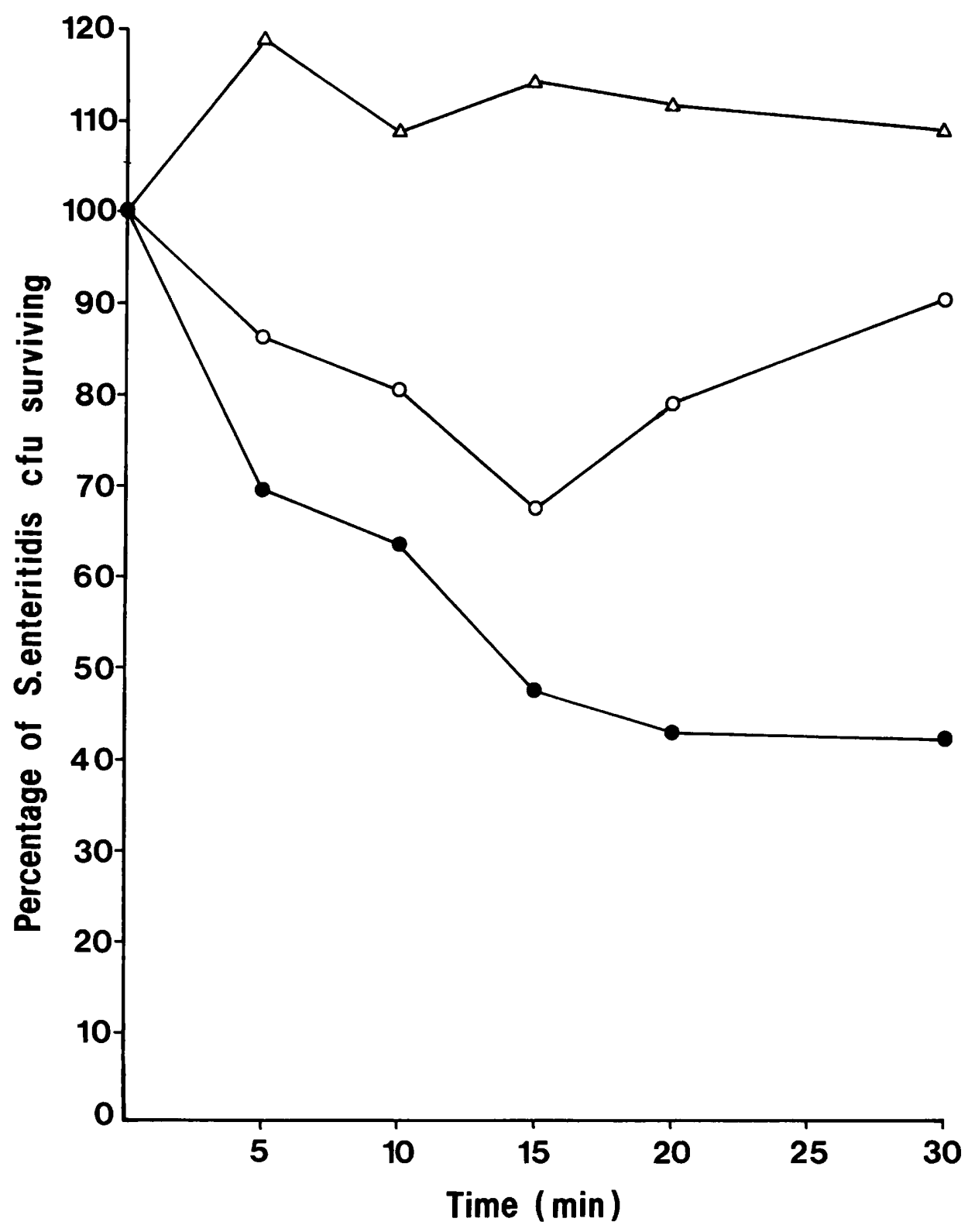

FIG. 5.-Microbicidal activity of peritoneal exudate cells from normal mice $36 \mathrm{~h}$ after challenge with $50 \mu \mathrm{g}$ of purified delayed-hypersensitivity-eliciting antigen of $M$. tuberculosis $\mathrm{H} 37 \mathrm{Rv}(\Delta-\Delta-\Delta)$, mice immunised with live $M$. tuberculosis $\mathrm{H} 37 \mathrm{Rv} 3$ months before the assay $(\mathrm{O}-\mathrm{O}-\mathrm{O})$, and mice immunised with live $M$. tuberculosis H37Rv 3 months before the assay and stimulated intraperitoneally with $50 \mu \mathrm{g}$ of purified delayed-hypersensitivity-eliciting antigen $36 \mathrm{~h}$ before the assay ( 
antiserum showed five precipitin peaks against the crude sonicate. This discrepancy may be explained by the possibility that the purified antigen contained impurities inadequate to produce precipitin arcs when the pure antigen was employed in the test assay, but adequate to induce antibody production in rabbits.

Mackaness (1967) has pointed out that delayed hypersensitivity does not necessarily indicate protective immunity. Hence it was essential to prove the ability of the purified delayed-hypersensitivity-eliciting antigen of strain $\mathrm{H} 37 \mathrm{Rv}$ to generate activated macrophages by T cell stimulation. Nair and Kamat (1982) have recently described a modification of the assay of Blanden, Mackaness and Collins (1966) of a soluble antigen to interact with effector $\mathrm{T}$ cells to generate activated macrophages. This assay was employed with the purified delayed-hypersensitivity-eliciting antigen of strain $\mathrm{H} 37 \mathrm{Rv}$ with an important modification. In the microbicidal assay of peritoneal exudate cells, mycobacteria could not be employed because a sensitive assay for the emumeration of live mycobacteria was not available. In view of the non-specific nature of activated macrophages, they were assayed with $S$. enteritidis, another facultative intracellular parasite which is killed efficiently by the same type of cell. In the assay system, the specificity was tested at the level of effector $T$ cell-antigen interaction that is essential to generate activated macrophages. The results proved unequivocally that the purified antigen could not only elicit delayed hypersensitivity but also stimulate the generation of activated macrophages. Hence it was concluded that the characterised antigen is a target for cell mediated immunity.

This work received financial assistance from the Indian Council of Medical Research.

\section{REFERENCES}

Blanden R V, Mackaness G B, Collins F M 1966 Mechanisms of acquired resistance in mouse typhoid. Journal of Experimental Medicine 124:585-600.

Daniel T M, Anderson P A 1978 The isolation by immunoabsorbent affinity chromatography and physico-chemical characterization of Mycobacterium tuberculosis antigen 5. American Review of Respiratory Diseases 117:533-539.

Daniel T M, Janicki B W 1978 Mycobacterial antigens: A review of their isolation, chemistry and immunological properties. Microbiological Reviews 42:84-113.

Deshpande J M, Sharma K D, Kamat R S 1982 Delayed hypersensitivity eliciting lipoprotein antigen of Mycobacterium tuberculosis H37Rv. Indian Journal of Medical Research 76:10-17.

Doub L, Youmans G P 1950 Studies in tuberculosis chemotherapy: Simple primary aromatic amines, in vitro and in vivo. American Review of Tuberculosis $61: 407-421$.

Gray D F, Jennings P A 1955 Allergy in experimental mouse tuberculosis. American Review of Respiratory Diseases 72:171-195.

Gupta K C, Landi S 1980 Isolation, characterization and biological properties of a tuberculin-active peptidoglycan isolated from culture filtrate of Mycobacterium tuberculosis. Infection and Immunity 27:344-350.

Hughes H P A, Lee D L, Balfour A H 1980 A multiple staining technique for agarose gels. Science Tools 27:39-43.

Kuwabara S, Tsumita T 1974 Primary structure of tuberculin-active protein from tubercule bacilli (letter). Japanese Journal of Experimental Medicine 44:129-132.

Laurell C B 1965 Antigen-antibody crossed electrophoresis. Analytical Biochemistry 10:358-361.

Lowry O H, Rosebrough N J, Farr A L, Randall R J 1951 Protein measurement with the folin phenol reagent. Journal of Biological Chemistry 193:265-275. 
Mackaness G B 1967 The relationship of delayed hypersensitivity to acquired cellular resistance. British Medical Bulletin 23:52-54.

Maizel J V 1971 Polyacrylamide gel electrophoresis of viral proteins. In: Maramorosch K, Koprowski H (eds) Methods in virology, vol. 5. Academic Press, New York, pp 176-246.

Nair R, Kamat R S 1982 Effector cell-mediated immune response in mice immunised with Salmonella. Journal of Medical Microbiology 15:215-221.

Ouchterlony O, Nilsson L A 1978 Immunodiffusion and immunoelectrophoresis. In: Weir D M (ed) Handbook of experimental immunology, 3rd edn. Blackwell Scientific Publications, Oxford, $\mathrm{p} 19.5$.

Vesterberg O 1980 Isoelectric focussing of proteins in agarose gels and detection of protein by different staining procedures. In: Radola B J (ed) Electrophoresis '79. Walter de Gruyter, Berlin, pp 95-106. 